TITLE:

\title{
Nitrogen and phosphorus effluent loads from a paddy-field district adopting collective crop rotation.
}

\section{$\operatorname{AUTHOR}(\mathrm{S})$ :}

Hama, T; Aoki, T; Osuga, K; Sugiyama, S; Iwasaki, D

\section{CITATION:}

Hama, T ... [et al]. Nitrogen and phosphorus effluent loads from a paddy-field district adopting collective crop rotation.. Water science and technology: a journal of the International Association on Water Pollution Research 2012, 66(5): 1074-1080

\section{ISSUE DATE:}

2012-05

URL:

http://hdl.handle.net/2433/178675

\section{RIGHT:}

(c) IWA Publishing 2012; This is not the published version. Please cite only the published version.; この論文は出版社版でありません。引用の 際には出版社版をご確認ご利用ください。 


\title{
Nitrogen and phosphorus effluent loads from a paddy-field district adopting collective crop rotation
}

\author{
T. Hama*, T. Aoki**, K. Osuga*, S. Sugiyama*, and D. Iwasaki*
}

\author{
* Graduate School of Agriculture, Kyoto University, Kitashirakawa Oiwake-cho, Sakyo Ward, Kyoto 606- \\ 8502, JAPAN \\ (E-mail: hama@kais.kyoto-u.ac.jp; kosugasuga@gmail.com; sho.sugiyama@ax5.ecs.kyoto-u.ac.jp; \\ sig@kais.kyoto-u.ac.jp; nakamura@kais.kyoto-u.ac.jp) \\ ** Tokyo Gas Co., Ltd., 1-5-20 Kaigan, Minato Ward, Tokyo 105-8527, JAPAN \\ (E-mail:t.aoki@tokyo-gas.co.jp)
}

\begin{abstract}
Japanese paddy rice systems commonly adopt the rotation of vegetables, wheat and soybeans with paddy rice. Crop rotation may, however, increase the nutrient load in effluent discharged from the district because more fertilizer is applied to the rotation crops than is applied to paddy crops. We investigated a paddy-field district subject to collective crop rotation and quantified the annual nutrient load of effluent from the district in three consecutive years. The total annual exports of nitrogen and phosphorus over the investigation period ranged from 30.3 to $40.6 \mathrm{~kg} \mathrm{~N} \mathrm{ha}^{-1}$ and 2.62 to $3.13 \mathrm{~kg} \mathrm{P} \mathrm{ha}{ }^{-1}$. The results suggest that rotation cropping increases the effluent nutrient load because applied fertilizer is converted to nitrate and surface runoff is increased due to the absence of shuttering boards at the field outlets.
\end{abstract}

Keywords

Nutrient loads; crop rotation; paddy-field district; wheat; non-irrigation period

\section{INTRODUCTION}

In Japan, the rotation of paddy rice, vegetables, wheat and soybeans is promoted to improve national food self-sufficiency and stabilize food supply. But paddy-field districts are usually located in low-lying areas unsuitable for cultivation of crops. To enable the rotation of such crops, an enhanced drainage system with underground drains is installed in each paddy field, and the rotation crops are timed to occur simultaneously across a contiguous area of adjoining fields in the district (collective crop rotation) to prevent waterlogging damage by lateral inflow of water from neighboring fields. Implementation of a crop rotation system may, however, increase the effluent nutrient load from the district because more fertilizer is applied to the rotation crops than to the paddy fields. The reduction of nutrients, suspended solids and organic matter load in drainage water from non-point sources is an important issue in water quality management (Gunes, 2008). Various environmental measures to reduce effluent load, such as the reduction of chemical fertilizer and reuse of drainage water (cyclic irrigation), are applied in paddy-field districts. Cyclic irrigation is particularly effective at reducing effluent load (Takeda et al., 1997; Kaneki et al., 2003; Feng et al., 2004, 2005; Hitomi et al., 2006; Takeda and Fukushima, 2006; Hama et al., 2010) and is one of the few district-scale environmental mitigation measures available in low-lying areas. Cyclic irrigation is only possible during the rice-growing season (the irrigation period), and the effluent loads from districts implementing collective crop rotation are unclear. We therefore investigated a paddy-field district implementing collective crop rotation for 3 years and quantified the annual effluent and nutrient loads from the district.

\section{MATERIALS AND METHODS}

\section{Study site}

The study site was a low-lying paddy-field district located on the southeastern edge of Lake Biwa $\left(35^{\circ} 05^{\prime} \mathrm{N}, 135^{\circ} 56^{\prime}\right.$ E, 86-88m above sea level; Figure 1), the largest lake in Japan and the most 
important water resource for the Kinki region. The mean annual temperature and rainfall are about $15{ }^{\circ} \mathrm{C}$ and 1550 mm (Japan Meteorological Agency, 2010). The district covers an area of about $1.5 \mathrm{~km}^{2}$, of which more than $90 \%$ is used as paddy fields.

The drainage and irrigation canals in the district are separated (Figure 2). There is no inflow of industrial or domestic wastewater from outside the study area into the drainage and irrigation canals. The drainage system contains lateral drainage canals, a main drainage canal, which passes through the district from north to south, and floodgates at both ends of the main drainage canal (Figure 1). Rainfall runoff from the paddy fields and surplus irrigation water from the irrigation canals flow into the main drainage canal via the lateral drainage canals. The floodgate at the northern end of the drainage canal was closed during the period of our investigation so that all outflow of drainage water from the district was controlled by operation of the southern floodgate.

Two types of irrigation are practiced in $\begin{aligned} & \text { the district: lake-water irrigation and } \\ & \text { cyclic irrigation. In lake-water irrigation, Rainfall }\end{aligned} \mid$ Evapotranspiration water is pumped from Lake Biwa into the irrigation canals. Under cyclic irrigation, drainage water in the main drainage canal is pumped into the irrigation canals and reused as irrigation water and water flows from the lake to the drainage canal through the floodgate when the water level of drainage water decreases by evapotranspiration. There are two pump stations, one at the

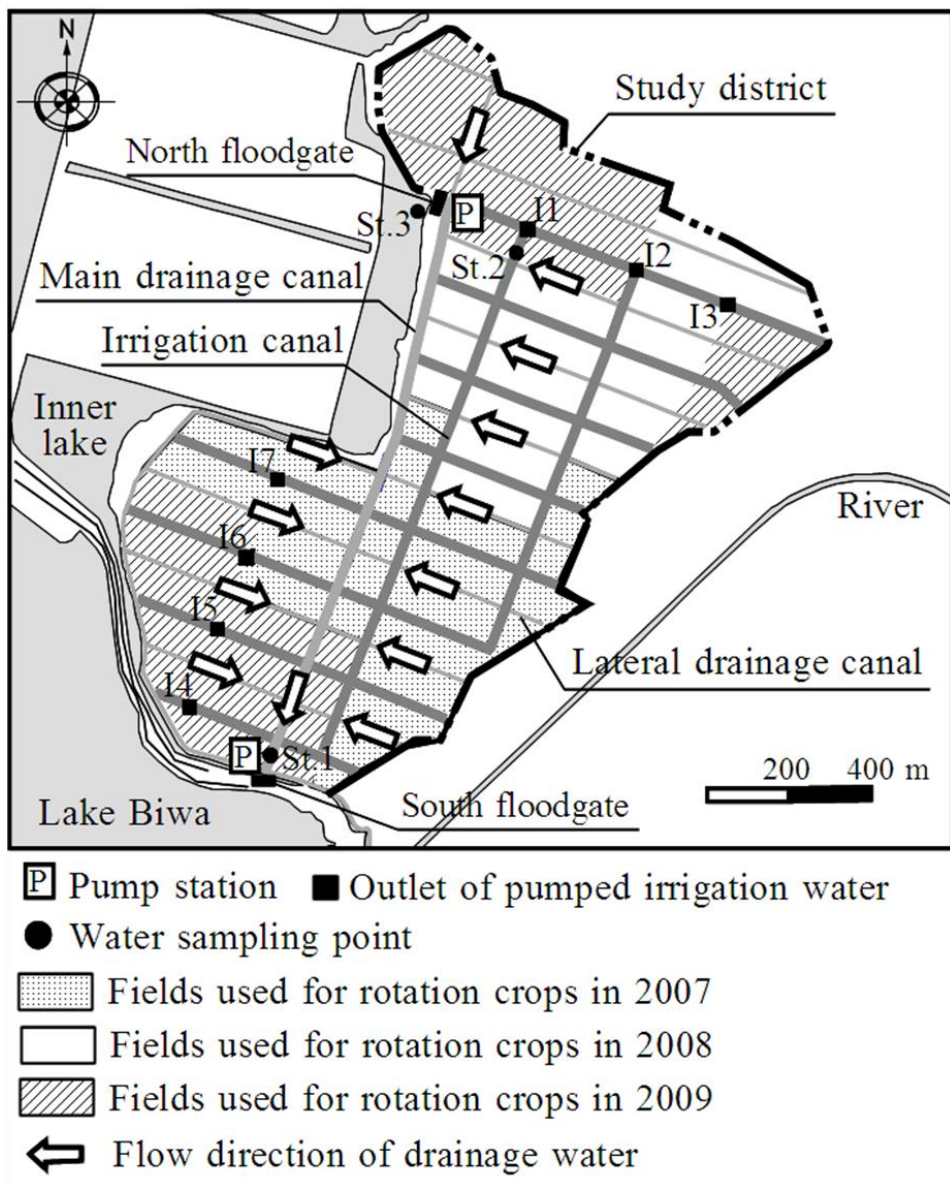

Figure 1. Layout of paddy fields, water source, pump stations and irrigation and drainage canals in the study area, an irrigation district used to investigate water balance and nutrient flows from 2007-2009.

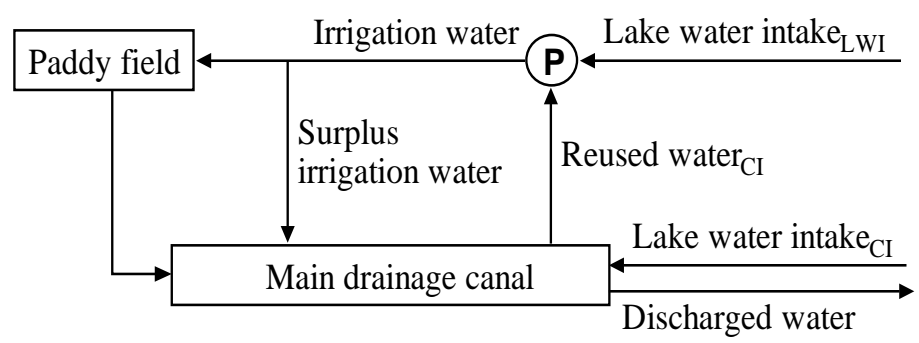

Figure 2. Flow diagram of water in the paddy-field district. CI, cyclic irrigation; LWI, lake-water irrigation. northern end and one at the southern end of the main drainage canal. The fields are not irrigated during the growing of rotation crops (i.e., crops other than paddy rice). The irrigation period is about 4 months, including a mid-summer drainage season of about 10 days. Cyclic irrigation is used from the beginning of the irrigation period to the mid-summer drainage season (referred to as the cyclic irrigation period), then lake-water irrigation is used until the end of the irrigation period (the lake-water irrigation period) because farmers wants to use cooler water for rice quality. The period from the end of the irrigation period to the beginning of the next irrigation period is referred to as the non-irrigation period. 
Table 1. The sequence of farming activities in the paddy-field district during the cultivation of paddy rice and cultivation of rotation crops.

\begin{tabular}{|c|c|c|c|c|c|}
\hline \multicolumn{3}{|c|}{ Paddy rice } & \multicolumn{3}{|c|}{ Rotation crops (wheat and soybeans) } \\
\hline Farming activity & Timing & Remarks $^{\mathrm{a}}$ & Farming activity & Timing & Remarks \\
\hline Base fertilization & late April & $\mathrm{N}=30, \mathrm{P}=30$ & Base fertilization & November & $\mathrm{N}=60, \mathrm{P}=80$ \\
\hline Start of irrigation & late April & & Sowing of wheat & November & \\
\hline Puddling, Sowing & late April-May & & Additional fertilization & late December & $\mathrm{N}=30, \mathrm{P}=30$ \\
\hline Additional fertilizaion & late June & $\mathrm{N}=10, \mathrm{P}=0$ & Additional fertilization & late February & $\mathrm{N}=30, \mathrm{P}=30$ \\
\hline Mid-summer drainage & late June - July & about 10 days & Additional fertilization & late April & $\mathrm{N}=20, \mathrm{P}=0$ \\
\hline Additional fertilizaion & mid July & $\mathrm{N}=50, \mathrm{P}=0$ & Harvesting & June & \\
\hline End of irrigation & late August & & Sowing of soybeans & June & after harvesting of wheat \\
\hline Harvesting & September & & Harvesting & November & \\
\hline
\end{tabular}

${ }^{\mathrm{a}} \mathrm{N}$, the amouts of ferilizer of nitrogen $\left(\mathrm{kgN} \mathrm{ha}^{-1}\right)$; $\mathrm{P}$, the amouts of ferilizer of phosphorus $\left(\mathrm{kgP} \mathrm{ha}^{-1}\right)$.

Rotation crops are grown in about one-third of the paddy area each year on a 3-year cycle (Figure 1). In rotation years, two rotation crops are grown, wheat and soybeans. The sequence of farming activities in paddy cultivation and rotation crop cultivation are summarized in Table 1 . The rotation cropping cycle extends for 1 year, beginning in November with the sowing of wheat, which follows the harvesting of rice in September. The wheat is harvested in the middle of the next June. A crop of soybeans is sown soon after the harvesting of wheat and harvested in late November. The area is then left fallow and re-planted to paddy rice the following April. Fertilizer was not applied to soybeans. Base fertilizer was not applied to paddy fields after crop rotation.

\section{Water quality and hydrological measurements}

We measured water quality within the district at weekly intervals from 2007 to 2009 by taking samples of drainage water at the southern end of the main drainage canal (St. 1; Figure 1), irrigation water at the outlet of the pump (St. 2), and inner lake water (St. 3). In addition, an automatic water sampler (3700 Full-Size Portable Sampler, Teledyne Isco Inc., Lincoln, NE, USA) was installed at St. 1 and used to sample drainage water daily at noon. A small plastic tank was set near the northern pump station to collect rainfall, which was sampled during the weekly field visits. The manually sampled water was analyzed for total nitrogen (TN), dissolved total nitrogen (DTN), ammonium nitrogen $\left(\mathrm{NH}_{4}-\mathrm{N}\right)$, nitrate nitrogen $\left(\mathrm{NO}_{3}-\mathrm{N}\right)$, nitrite nitrogen $\left(\mathrm{NO}_{2}-\mathrm{N}\right)$, total phosphorous $(\mathrm{TP})$ and phosphate phosphorus $\left(\mathrm{PO}_{4}-\mathrm{P}\right)$. Drainage water samples from the automatic sampler and rainfall water samples from the rainwater collection tank were analyzed for TN and TP. The following analytical methods were used: TN and DTN were measured using an ultraviolet spectrophotometer (UV-1200, Shimadzu Corp., Kyoto, Japan) after alkaline potassium-peroxydisulfate digestion; $\mathrm{NH}_{4}$ $\mathrm{N}$ was measured by the indo-phenol blue method; $\mathrm{NO}_{3}-\mathrm{N}$ was measured by ion chromatography (LC-10A, Shimadzu Corp.); $\mathrm{NO}_{2}-\mathrm{N}$ was measured by the $\mathrm{N}$-(1-naphthyl) ethylenediamine method; TP was measured by the molybdenum blue method after potassium-peroxydisulfate digestion; and $\mathrm{PO}_{4}-\mathrm{P}$ was measured by the molybdenum blue method. Particulate-state and dissolved-state nutrients were distinguished by filtering the sample with a $1-\mu \mathrm{m}$ filter prior to analysis.

Meteorological instruments for measuring rainfall (RT-5E, Ikeda-Keiki, Tokyo, Japan), air temperature (CS215L, Campbell Scientific, Inc., Logan, UT, USA), wind velocity (014A-L, Campbell Scientific, Inc.), relative humidity (CS215L, Campbell Scientific, Inc.) and solar radiation (LP02-L, Campbell Scientific, Inc.) were installed in an open area at the southern pump station. Evapotranspiration during the irrigation period was estimated by the Penman method (Penman, 1948) using data measured at the southern pump station and the crop coefficient value for rice (Sakuratani and Horie, 1985). Evapotranspiration during the non-irrigation period was estimated from the water balance for the district. The flow rates of discharged drainage water during lakewater irrigation or on rainy days and inflowing lake water during cyclic irrigation were measured 
using flow meters (2150 Area Velocity Flow Module, Teledyne Isco Inc.) installed at both ends of the main drainage canal. The volume of pumped water (= irrigation water for the district) was estimated by multiplying the operating duration of the pumps by their capacity. We did not measure subsurface percolation from the district, but assumed it to be negligible because the district is lowlying and close to the lake and the groundwater level is high.

The water balances were calculated for a fixed portion of the irrigation period in each year for comparability. The irrigation period and non-irrigation period were respectively set from 20 April to 30 September and from 1 October to 19 April of the next year. The two periods of different irrigation type were marked as occurring before and after 1 July: cyclic irrigation was from 20 April to 30 June and lake-water irrigation was from 1 July to 30 September. Daily inputs and exports of nutrients were estimated by multiplying water nutrient concentrations by flow volumes.

\section{RESULTS AND DISCUSSION}

\section{Water balance}

Figure 3 shows daily variations in rainfall and outflow of water from the district. During the cyclic irrigation period, drainage water was mainly discharged in association with rainfall events, whereas during the lake-water irrigation periods drainage water of $10-15 \mathrm{~mm} \mathrm{~d}^{-1}$ was released even on fine days (rainfall $=0 \mathrm{~mm} \mathrm{~d}^{-1}$ ). During the lake-water irrigation periods, drainage water on fine days was the sum of surplus irrigation water (i.e., intake water not used to irrigate paddy fields) and lateral water flow from the paddy fields to the drainage canals (Figure 2). The amount of lateral water flow was estimated at 3-5 $\mathrm{mm} \mathrm{d}^{-1}$ from previous research on the paddy fields (Hama et al., 2011). This low contribution from lateral flow indicated that surplus irrigation water was the main source of drainage water discharged on fine days during lake-water irrigation. During the non-irrigation period, water was only discharged during rainfall events because no irrigation water was taken in.

Water balances for the district in each investigation period are shown in Table 2. Annual rainfall ranged from $1332 \mathrm{~mm}$ in 2009 to $1633 \mathrm{~mm}$ in 2007 . Weather conditions in the investigation years were considered normal because the amounts of annual rainfall were within the range of the mean \pm standard deviation $(1549 \pm 291 \mathrm{~mm})$ from three decades of data (1980-2009; Japan Meteorological Agency, 2010).

The cyclic irrigation ratio is the proportion of irrigation water that is reused and is an indicator of the intensity of the cycling of irrigation water. The difference between the total amount of pumped water (irrigation water) and lake water intake represents the amount of water reused in cyclic irrigation. The amounts of irrigation water during the cyclic irrigation periods were $965 \mathrm{~mm}$ in 2007, $964 \mathrm{~mm}$ in 2008 and $1046 \mathrm{~mm}$ in 2009, and the amounts of reused

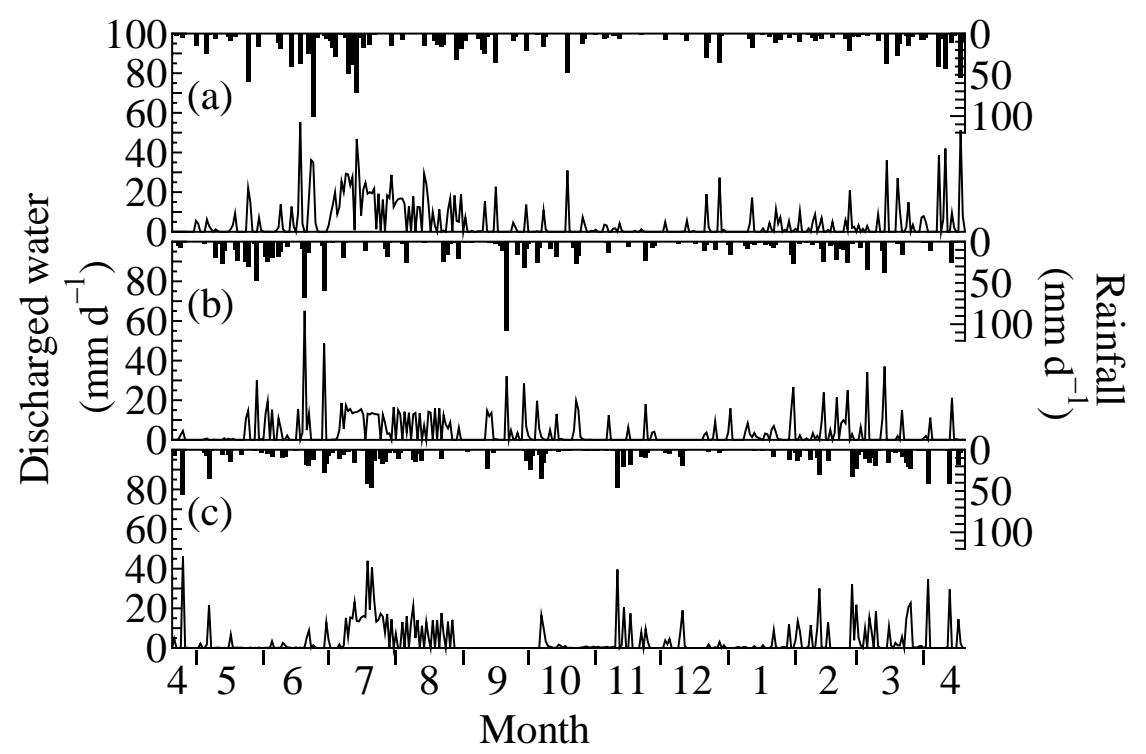

Figure 3. Daily variation in rainfall and discharged water in (a) 2007-2008, (b) 2008-2009 and (c) 2009-2010. 
Table 2. Water balances for the district in each year and the irrigation management phase of the investigation period.

\begin{tabular}{|c|c|c|c|c|c|}
\hline \multirow[b]{2}{*}{ Year } & \multirow[b]{2}{*}{ Period $^{\mathrm{a}}$} & \multicolumn{2}{|r|}{ Inflow } & \multicolumn{2}{|c|}{ Outflow } \\
\hline & & $\begin{array}{l}\text { Rainfall } \\
\text { (mm) }\end{array}$ & $\begin{array}{l}\text { Lake water intake } \\
\text { (mm) }\end{array}$ & $\begin{array}{l}\text { Evapotranspiration } \\
\text { (mm) }\end{array}$ & $\begin{array}{l}\text { Discharged water } \\
\text { (mm) }\end{array}$ \\
\hline \multirow[t]{4}{*}{2007} & Cyclic irrigation & 405 & 173 & 277 & 277 \\
\hline & Lake-water irrigation & 565 & 677 & 376 & 919 \\
\hline & Non-irrigation & 663 & 0 & 59 & 558 \\
\hline & Total & 1633 & 850 & 712 & 1754 \\
\hline \multirow[t]{4}{*}{2008} & Cyclic irrigation & 481 & 100 & 277 & 285 \\
\hline & Lake-water irrigation & 347 & 648 & 442 & 610 \\
\hline & Non-irrigation & 600 & 0 & 65 & 527 \\
\hline & Total & 1428 & 748 & 784 & 1422 \\
\hline \multirow[t]{4}{*}{2009} & Cyclic irrigation & 280 & 168 & 287 & 124 \\
\hline & Lake-water irrigation & 331 & 605 & 365 & 583 \\
\hline & Non-irrigation & 721 & 0 & 61 & 622 \\
\hline & Total & 1332 & 773 & 713 & 1329 \\
\hline
\end{tabular}

${ }^{a}$ Cyclic irrigation $=20$ April -30 June; Lake-water irrigation $=1$ July -30 September; Non-irrigation $=1$ October - 19 April.

water were therefore $792 \mathrm{~mm}$ in 2007, $864 \mathrm{~mm}$ in 2008 and $878 \mathrm{~mm}$ in 2009. The cyclic irrigation ratio in the district was $82 \%$ in $2007,90 \%$ in 2008 and $84 \%$ in 2009 . Under the lake-water irrigation system, the amount of lake water intake approximately equals to that of irrigation water.

The amount of water discharged was low during the cyclic irrigation periods, because of the reuse of drainage water, and high during the lake-water irrigation and non-irrigation periods (Figure 3). The amount of water discharged during the non-irrigation period was proportional to rainfall. The water storage capacity of the paddy fields is likely to be lowest during the non-irrigation period because the shutter boards at the outlets of the paddy fields are removed and the outlets of the underground drainpipes are open.

\section{Temporal variation in nutrient concentrations}

Figure 4 shows the daily variation in TN and TP concentrations in drainage water. The nutrient concentrations were higher during the puddling season and on days on which rain fell. Nutrient concentrations on fine days during the irrigation period ranged from 1.0 to $2.0 \mathrm{mg} \mathrm{N} \mathrm{L}^{-1}$ for TN and from 0.10 to $0.20 \mathrm{mg} \mathrm{P} \mathrm{L}^{-1}$ for TP. The nutrient concentrations in the drainage water were higher

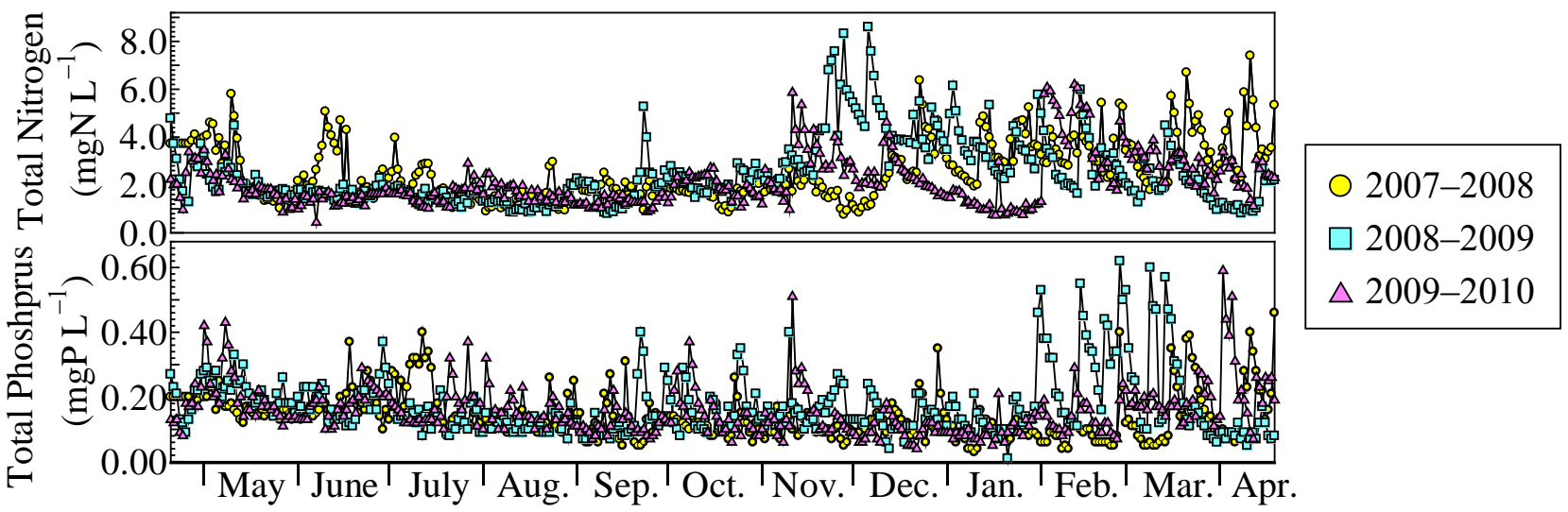

Figure 4. Daily variations in TN and TP in drainage water in 2007-2009. 
Table 3. Mean \pm standard deviation of the concentration of total nitrogen (TN), dissolved TN (DTN), $\mathrm{N}$ as ammonia $\left(\mathrm{NH}_{4}-\mathrm{N}\right), \mathrm{N}$ as nitrate $\left(\mathrm{NO}_{3}-\mathrm{N}\right), \mathrm{N}$ as nitrite $\left(\mathrm{NO}_{2}-\mathrm{N}\right)$, total phosphorus (TP) and $\mathrm{P}$ as phosphate $\left(\mathrm{PO}_{4}-\mathrm{P}\right)$ in drainage water during the different irrigation management phases in 2009.

\begin{tabular}{|c|c|c|c|c|c|c|c|c|}
\hline \multirow{2}{*}{ Period $^{\mathrm{a}}$} & $\mathrm{TN}$ & DTN & $\mathrm{NH}_{4}-\mathrm{N}$ & $\mathrm{NO}_{3}-\mathrm{N}$ & $\mathrm{NO}_{2}-\mathrm{N}$ & $\mathrm{TP}$ & $\mathrm{PO}_{4}-\mathrm{P}$ & \multirow{2}{*}{$n^{\mathrm{b}}$} \\
\hline & $\left(\mathrm{mg} \mathrm{N} \mathrm{L}^{-1}\right)$ & $\left(\mathrm{mg} \mathrm{N} \mathrm{L}^{-1}\right)$ & $\left(\mathrm{mg} \mathrm{N} \mathrm{L}^{-1}\right)$ & $\left(\mathrm{mg} \mathrm{N} \mathrm{L}^{-1}\right)$ & $\left(\mathrm{mg} \mathrm{N} \mathrm{L}^{-1}\right)$ & $\left(\mathrm{mg} \mathrm{P} \mathrm{L}^{-1}\right)$ & $\left(\mathrm{mg} \mathrm{P} \mathrm{L}^{-1}\right)$ & \\
\hline CI & $2.07 \pm 0.84$ & $1.41 \pm 0.77$ & $0.20 \pm 0.09$ & $0.71 \pm 0.62$ & $0.04 \pm 0.01$ & $0.24 \pm 0.10$ & $0.05 \pm 0.04$ & 11 \\
\hline LWI & $1.48 \pm 0.44$ & $0.98 \pm 0.49$ & $0.20 \pm 0.18$ & $0.35 \pm 0.25$ & $0.03 \pm 0.02$ & $0.14 \pm 0.05$ & $0.03 \pm 0.02$ & 10 \\
\hline Non-I & $2.94 \pm 1.55$ & $2.48 \pm 1.58$ & $0.10 \pm 0.13$ & $2.02 \pm 1.71$ & $0.01 \pm 0.01$ & $0.15 \pm 0.10$ & $0.04 \pm 0.02$ & 31 \\
\hline
\end{tabular}

${ }^{\mathrm{a}}$ CI, cyclic irrigation; LWI, lake water irrigation; Non-I, non-irrigation. ${ }^{\mathrm{b}}$ The number of samples.

during the cyclic irrigation period than during the lake-water irrigation period. These trends in nutrient concentrations in the drainage water were similar in all three years of the investigation. The nitrogen concentration in drainage water was high even on fine days during the non-irrigation period, presumably because of nitrogen derived from fertilizer applied to wheat crops.

Table 3 shows the mean concentration of nitrogen and phosphorus and each of their measured forms in drainage water in 2009. DTN was about 60-70\% of TN during the irrigation periods, but increased to $>80 \%$ of TN during the non-irrigation period. Similarly, the concentration of $\mathrm{NO}_{3}-\mathrm{N}$ and its percentage of DTN were higher during the non-irrigation period. The higher $\mathrm{NO}_{3}-\mathrm{N}$ in runoff presumably was derived from the nitrification of $\mathrm{NH}_{4}-\mathrm{N}$ in fertilizer or soil organic matter when the soil became aerobic during the cultivation of rotation crops.

\section{Effluent nutrient loads}

The inputs of TN and TP in rainfall and lake water and exports of TN and TP in discharged water during the different phases of irrigation management are shown in Table 4. The total annual exports of nitrogen and phosphorus ranged from 30.3 to $40.6 \mathrm{~kg} \mathrm{~N} \mathrm{ha}^{-1}$ and 2.62 to $3.13 \mathrm{~kg} \mathrm{P} \mathrm{ha}^{-1}$, respectively. The export of nutrients was least during the cyclic irrigation periods, in line with the

Table 4. Inputs and outputs of nutrients by rainfall, extracted lake water and discharged water and nutrients exported during each irrigation management phase in the three years of the investigation.

\begin{tabular}{|c|c|c|c|c|c|c|c|}
\hline \multirow{3}{*}{ Year } & \multirow{3}{*}{ Period $^{\mathrm{a}}$} & \multicolumn{3}{|c|}{ Total Nitrogen } & \multicolumn{3}{|c|}{ Total Phosphorus } \\
\hline & & \multicolumn{2}{|c|}{ Inputs $^{\mathrm{b}}$} & \multirow{2}{*}{$\begin{array}{c}\text { Exports }^{\mathrm{c}} \\
\mathrm{D} \\
\left(\mathrm{kg} \mathrm{N} \mathrm{ha}^{-1}\right)\end{array}$} & \multicolumn{2}{|c|}{ Inputs } & \multirow{2}{*}{$\begin{array}{c}\text { Exports } \\
\mathrm{D} \\
\left(\mathrm{kg} \mathrm{P} \mathrm{ha}^{-1}\right)\end{array}$} \\
\hline & & $\begin{array}{c}\mathrm{R} \\
\left(\mathrm{kg} \mathrm{N} \mathrm{ha}^{-1}\right)\end{array}$ & $\begin{array}{c}\mathrm{L} \\
\left(\mathrm{kg} \mathrm{N} \mathrm{ha}^{-1}\right)\end{array}$ & & $\begin{array}{c}\mathrm{R} \\
\left(\mathrm{kg} \mathrm{P} \mathrm{ha}^{-1}\right)\end{array}$ & $\begin{array}{c}\mathrm{L} \\
\left(\mathrm{kg} \mathrm{P} \mathrm{ha}^{-1}\right)\end{array}$ & \\
\hline \multirow[t]{4}{*}{2007} & Cyclic irrigation & 3.2 & 2.8 & 5.9 & 0.08 & 0.20 & 0.63 \\
\hline & Lake-water irrigation & 4.5 & 4.6 & 16.1 & 0.10 & 0.39 & 1.66 \\
\hline & Non-irrigation & 5.2 & 0.0 & 18.6 & 0.12 & 0.00 & 0.84 \\
\hline & Total & 12.9 & 7.4 & 40.6 & 0.30 & 0.59 & 3.13 \\
\hline \multirow[t]{4}{*}{2008} & Cyclic irrigation & 2.8 & 1.2 & 4.6 & 0.09 & 0.07 & 0.58 \\
\hline & Lake-water irrigation & 2.0 & 2.1 & 8.8 & 0.06 & 0.15 & 0.82 \\
\hline & Non-irrigation & 3.5 & 0.0 & 16.9 & 0.11 & 0.00 & 1.28 \\
\hline & Total & 8.3 & 3.3 & 30.3 & 0.26 & 0.22 & 2.68 \\
\hline \multirow[t]{4}{*}{2009} & Cyclic irrigation & 1.9 & 1.4 & 2.6 & 0.05 & 0.09 & 0.27 \\
\hline & Lake-water irrigation & 2.2 & 3.3 & 8.7 & 0.06 & 0.17 & 0.93 \\
\hline & Non-irrigation & 4.9 & 0.0 & 22.1 & 0.13 & 0.00 & 1.42 \\
\hline & Total & 9.0 & 4.7 & 33.4 & 0.24 & 0.26 & 2.62 \\
\hline
\end{tabular}

\footnotetext{
${ }^{\mathrm{a}}$ Cyclic irrigation $=20$ April -30 June; Lake-water irrigation $=1$ July -30 September; Non-irrigation $=1$ October -
} 19 April. ${ }^{b} \mathrm{R}$, input of nutrients in rainfall; $\mathrm{L}$, input of nutrients in lake water. ${ }^{\mathrm{c}} \mathrm{D}$, export of nutrients in discharged water. 
small amounts of water discharged (Table 2). Some of the nutrient exports during periods of lakewater irrigation were caused by the discharge of surplus irrigation water on fine days (Figure 3), although nutrient concentrations in the drainage water were lower than during cyclic irrigation (Table 3).

Figure 5 shows the relationships between daily flow rate of discharged water $\left(\mathrm{m}^{3} \mathrm{~d}^{-1}\right)$ and the nutrients load in effluent $\left(\mathrm{kg} \mathrm{d}^{-1}\right)$. The mean concentrations of nitrogen in the discharged water during the irrigation periods were significantly different ( $p<0.05$, Turkey's test), though the mean concentrations of phosphorus during the irrigation periods were not significantly different, except between the cyclic irrigation period and lake-water irrigation period $(p<0.05)$. The equations for the linear regression lines for both nitrogen and phosphorus in Figure 5 are shown in Table 5. The regression coefficients have units of concentration, $\mathrm{kg} \mathrm{m}^{-3}\left(\times 10^{3} \mathrm{mg} \mathrm{L}^{-1}\right)$, and in each equation may be considered representative of the concentration of the nutrient discharged during the period.

Nitrogen and phosphorus concentrations were lowest during the lake-water irrigation period, higher during the cyclic irrigation period and highest during the non-irrigation period. The high nitrogen concentration during the non-irrigation period was caused by $\mathrm{NO}_{3}-\mathrm{N}$, presumably because it is less

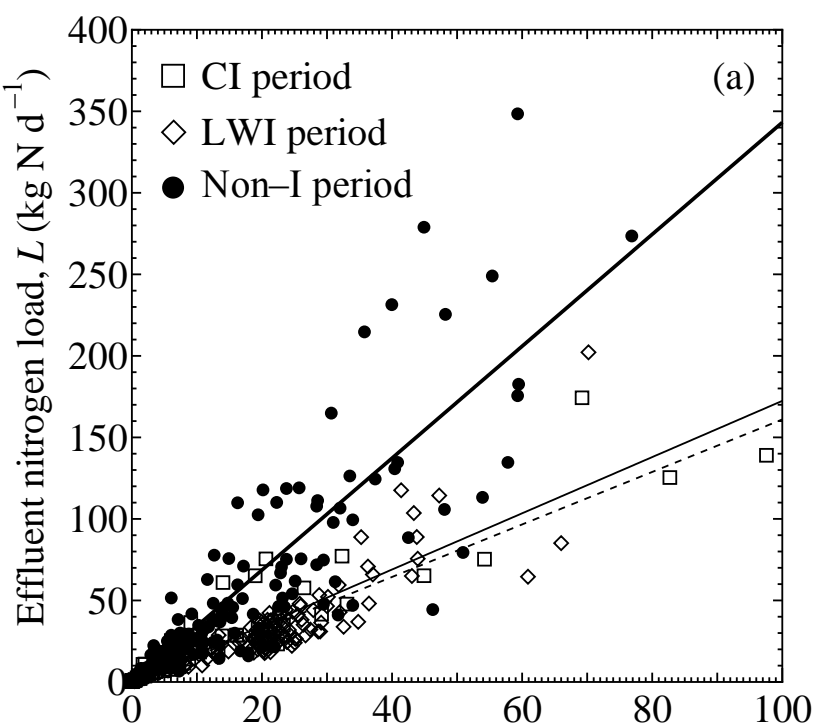

Flow rate of discharged water, $Q\left(\times 10^{3} \mathrm{~m}^{3} \mathrm{~d}^{-1}\right)$

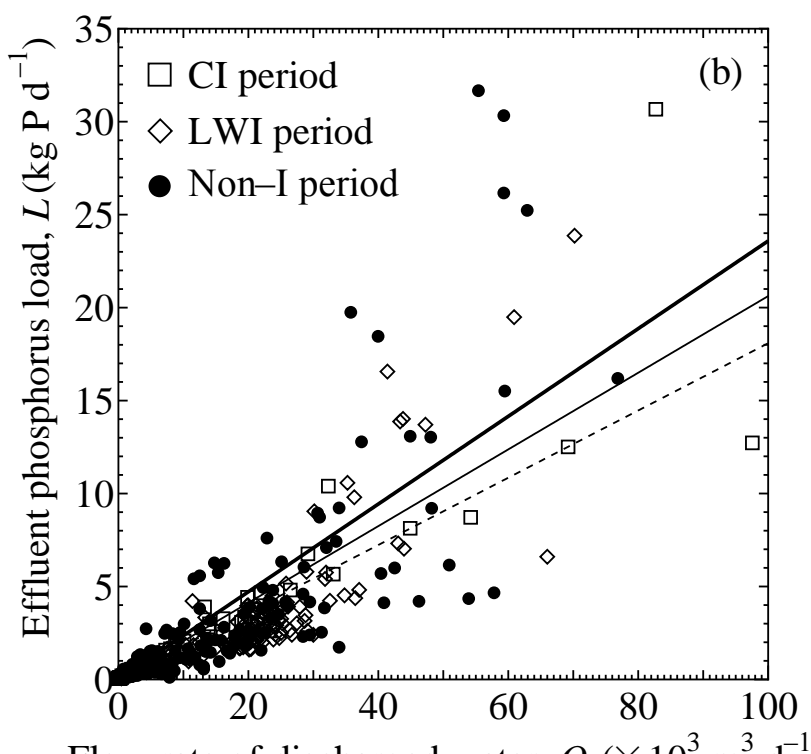

Flow rate of discharged water, $Q\left(\times 10^{3} \mathrm{~m}^{3} \mathrm{~d}^{-1}\right)$

Figure 5. Scatter plots and regression relationships between daily discharged water and (a) nitrogen and (b) phosphorus load in effluent during cyclic irrigation (CI), lake-water irrigation (LWI) and non-irrigation $($ Non-I). Thin line $=$ CI period; dash line $=$ LWI period; thick line $=$ Non-I period .

Table 5. Regression relationships between daily nutrient load in discharged effluent and daily effluent discharge rate for each phase of irrigation management. All significant levels are $0.1 \%$.

\begin{tabular}{lcccc}
\hline \multirow{1}{*}{ Period $^{\mathrm{a}}$} & \multicolumn{2}{c}{ Nitrogen } & \multicolumn{2}{c}{ Phosphorus } \\
\cline { 2 - 6 } & $\begin{array}{c}\text { Regression equation }^{\mathrm{b}} \\
\left(\mathrm{kg} \mathrm{N} \mathrm{d}^{-1}\right), Q\left(\mathrm{~m}^{3} \mathrm{~d}^{-1}\right)\end{array}$ & $\mathrm{R}^{2}$ & $\begin{array}{c}\text { Regression equation } \\
L\left(\mathrm{~kg} \mathrm{P} \mathrm{d}^{-1}\right), Q\left(\mathrm{~m}^{3} \mathrm{~d}^{-1}\right)\end{array}$ & $\mathrm{R}^{2}$ \\
\hline Cyclic irrigation & $L=1.72 \times 10^{-3} Q$ & 0.88 & $L=2.06 \times 10^{-4} Q$ & 0.81 \\
Lake-water irrigation & $L=1.61 \times 10^{-3} Q$ & 0.71 & $L=1.81 \times 10^{-4} Q$ & 0.60 \\
Non-irrigation & $L=3.43 \times 10^{-3} Q$ & 0.76 & $L=2.36 \times 10^{-4} Q$ & 0.66 \\
\hline
\end{tabular}

${ }^{a}$ Cyclic irrigation $=20$ April -30 June; Lake-water irrigation $=1$ July -30 September; Non-irrigation $=1$ October -19 April. ${ }^{\mathrm{b}}$ L, daily nutrient lood in effluent; Q, daily flow rate of discharged water. 
strongly adsorbed to the soil than $\mathrm{NH}_{4}-\mathrm{N}$ and thus easily removed from the paddy fields in runoff from rainfall events. Nutrient loads per unit of discharged water during rainfall events are therefore likely to be higher during non-irrigation periods than irrigation periods.

\section{CONCLUSIONS}

We found that high effluent nutrient loads were associated with rainfall during the non-irrigation period. Our findings suggest that the cultivation of rotation crops over one-third of the paddy-field district contributes to an increase in effluent nutrient loads from the district. Fertilizer applied to rotation crops is easily transported in surface runoff, and more runoff occurs in the non-irrigation period than during the irrigation period because all drainage outlets from the field are left open. These results suggest that rotation farming in low-lying paddy-field districts is a significant nonpoint pollution source that should be mitigated through the development of best management practices for rotation crops.

\section{ACKNOWLEDGEMENTS}

We thank the Konohama Agricultural Union and the Shiga Prefecture Office for providing access to the paddy plots for investigation and for providing daily reports on water management and farming activity in the paddy fields. The research described in this paper was partly funded by a Grant-inAid for Scientific Research from the Japan Society for the Promotion of Science.

\section{REFERENCES}

Feng, Y. W., Yoshinaga, I., Shiratani, E., Hitomi, T., \& Hasebe H. 2004. Characteristics and behavior of nutrients in a paddy field area equipped with a recycling irrigation system. Agric. Water Manage. 68, 47-60.

Feng, Y. W., Yoshinaga, I., Shiratani, E., Hitomi, T., \& Hasebe H. 2005. Nutrient balance in a paddy field with a recycling irrigation system, Water Sci. Technol. 51(3), 151-157.

Gunes, K. 2008. Point and nonpoint sources of nutrients to lakes - ecotechnological measures and mitigation methodologies - case study, Ecol. Eng. 34, 116-126.

Hama, T., Nakamura, K., \& Kawashima, S. 2010. Effectiveness of cyclic irrigation in reducing suspended solids load from a paddy-field district, Agric. Water Manage. 97, 483-489.

Hama, T., Nakamura, K., Kawashima, S., Kaneki, R., \& Mitsuno, T. 2011. Effects of cyclic irrigation on water and nitrogen mass balances in a paddy field. Ecol. Eng. 37, 1563-1566.

Hitomi, T., Yoshinaga, I., Feng, Y. W., \& Shiratani, E. 2006. Nitrogen removal function of recycling irrigation system. Water Sci. Technol. 53(2), 101-109.

Japan Meteorological Agency. 2010. Automated Meteorological Data Acquisition System (AMeDAS), URL http://www.jma.go.jp, (accessed 1 July 2010).

Kaneki, R. 2003. Reduction of effluent nitrogen and phosphorus from paddy fields. Paddy Water Environ. 1, 133-138.

Penman, H. L. 1948. Natural evaporation from open water, bare soil and grass. Proc. Royal Soc. Lond. A, 193, 120-145.

Sakuratani, T. \& Horie, T. 1985. Studies on evapotranspiration from crops, 1: On seasonal changes, vertical differences and the simplified methods of estimate in evapotranspiration of paddy rice. J. Agric. Meteorol. 41(1), 45-55 (in Japanese).

Takeda, I., Fukushima, A. \& Tanaka, R. 1997. Non-point pollutant reduction in a paddy-field watershed using a cyclic irrigation system. Water Res. 31, 2685-2692.

Takeda, I. \& Fukushima, A. 2006. Long-term changes in pollutant load outflows and purification function in a paddy field watershed using a cyclic irrigation system. Water Res. 40, 569-578. 